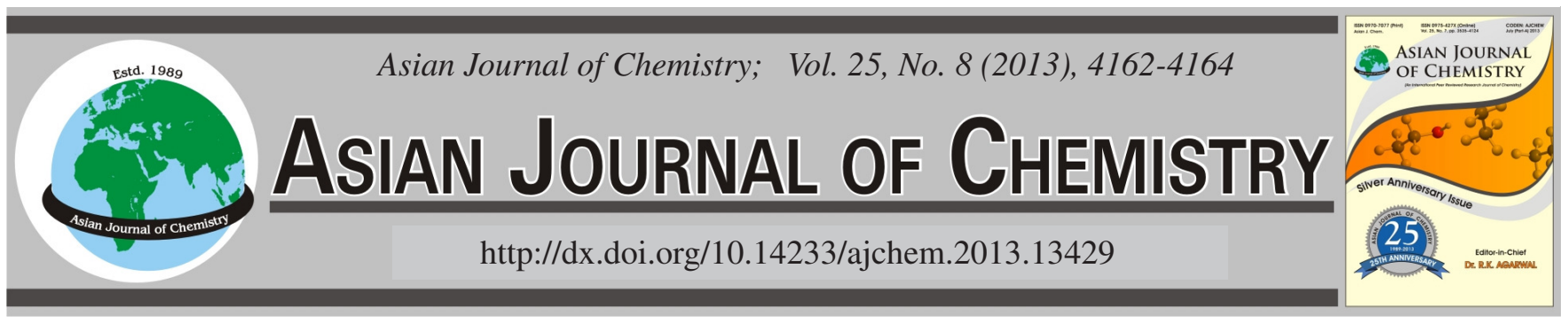

\title{
Reaction Between Trimethyl phosphite, Dimethyl Acetylenedicarboxylate and \\ 1,3-Dicarbonyl Compounds: An Efficient Method for the Synthesis of Dimethoxyphosphoryl Succinic Acid Dimethoxy Ester Derivatives
}

\author{
MARYAM YAZDANIAN and Ali AsAdipour ${ }^{*}$ \\ Department of Medicinal Chemistry, Faculty of Pharmacy, Kerman University of Medical Sciences, Kerman, Iran \\ *Corresponding author: Tel: +98 341 3205003; E-mail: aliasadipour@yahoo.com; aliasadipour@kmu.ac.ir
}

(Received: 30 January 2012;

Accepted: 4 February 2013)

AJC-12918

\begin{abstract}
The addition of a phosphorus nucleophile to an acceptor such as alkyne, certainly represents one of the most versatile and powerful tools for the formation of P-C bonds. This offers the possibility to access many diversely functionalized products. In this article, the reaction between trimethyl phosphite and dimethyl acetylenedicarboxylate (DMAD) with 1,3-dicarbonyl compounds such as dimedone, acetyl acetone and diethyl malonate proceeds smoothly to produce stable dimethoxyphosphoryl succinic acid dimethyl ester derivatives (4), (11) and (12) in excellent yields.
\end{abstract}

Key Words: Phosphite, Acetylenedicarboxylate, Dimedone, Phosphoryl succinic acid dimethyl ester.

\section{INTRODUCTION}

Phosphorus compounds have emerged to be tremendously important for many different areas in chemistry and especially in organic synthesis ${ }^{1}$. Interest in the preparation of organophosphorus compounds has continued to expand in recent years. This is a direct result of developing applications for phosphorus compounds in numerous synthetic procedures as well as an understanding of the role of the element in biological systems. The several classical efforts in regard to applications of organophosphorus compounds-the preparation of insecticides, agricultural chemicals, flame retardants, medicinal agents and reagents for olefination reactions- continue to be highly active topics in organophosphorus chemistry ${ }^{2}$. Organophosphorus compounds are being used as versatile intermediates in synthetic chemistry ${ }^{3-5}$. Especially, the structure of compounds which a carbon atom is directly bound to a phosphorus atom, are synthetic target of interest, not least because of their value for a variety of industrial, or biological activity and are useful in chemical synthesis. The physical properties and chemical reactivity of phosphate esters interlinks many areas in chemistry and biology. Introduction of a phosphate monoester into a molecule such as a drug candidate enhances the water solubility, hence altering its bioavailability ${ }^{6-8}$. Thus, a large number of methods have indicated novel synthesis of organophosphorus compounds. There are many studies on the reaction between trivalent phosphorus nucleophiles and $\alpha, \beta$ unsaturated carbonyl compounds in the presence of a proton source such as alcohol, phenol ${ }^{9-11}$ or $\mathrm{NH}$-acids ${ }^{12}$. Moreover it is reported the diastereoselective synthesis of meso-bisphosphonates in the presence of 4-nitrophenol ${ }^{13}$. We described herein the synthesis of a new series of dimethoxyphosphoryl succinic acid dimethoxy ester derivatives (4), (11) and (12) from the reaction of trimethyl phosphite and dimethyl acetylenedicarboxylate (DMAD) in the presence of 1,3-dicarbonyl compounds such as dimedone, acetyl acetone and diethyl malonate.

\section{EXPERIMENTAL}

Most of the chemical compounds were commerically available and were purchased from Merck company and used without further purification. Melting points were determined on an electrothermal 9100 apparatus. The IR spectra were recorded on a Shimadzu 470 spectrometer. ${ }^{1} \mathrm{H}$ NMR spectra were appropriately recorded on a BRUKER FT-80 spectrometer. Elemental analyses were performed by using a Heraeus CHNO-rapid analyzer. Their results were found to agree favourably with the calculated values.

Preparation of compound (4), (11), (12): To a stirred solution of 1,3-dicarbonyl compound ( $2 \mathrm{mmol}$ ) in $20 \mathrm{~mL}$ diethyl ether was added $2 \mathrm{~mL}$ trimethyl phosphite $(2 \mathrm{mmol})$ and $2 \mathrm{~mL}$ dimethyl acetylenedicarboxylate $(2 \mathrm{mmol})$ dropwise over $15 \mathrm{~min}$ at $-5^{\circ} \mathrm{C}$. The reaction mixture was allowed to room temperature and stirred for $48 \mathrm{~h}$. The solvent was evaporated and the residue was crystallized from ethanol to produce the pure product. 
2-(Dimethoxy-phosphoryl) -3-(2-hydroxy-4,4dimethyl-6-oxo-cyclohex-1-enyl)succinic acid dimethyl ester (4): Whitecrystals, m.p. $171.3{ }^{\circ} \mathrm{C}, 0.73 \mathrm{~g}$ (91\% yield); Anal. calcd.: C, 46.83; H, 5.94. Found: C, 48.98; H, $6.42 \%$. IR $\left(\mathrm{KBr}, \mathrm{v}_{\max }, \mathrm{cm}^{-1}\right)$ : 3125-3450 (broad peak, OH), 1780 $(\mathrm{C}=\mathrm{O}), 1630(\mathrm{C}=\mathrm{C}), 1230(\mathrm{P}=\mathrm{O}), 900\left(\mathrm{POCH}_{3}\right) ;{ }^{1} \mathrm{H}$ NMR $(80$ $\left.\mathrm{MHz}_{2} \mathrm{CDCl}_{3}\right): 1.09$ (s, 6H, 2CH$\left.)_{3}\right), 2.25\left(\mathrm{~m}, 4 \mathrm{H}, 2 \mathrm{CH}_{2}\right), 3.59$ $\left(\mathrm{d}, 3 \mathrm{H}, \mathrm{OCH}_{3}\left(\mathrm{P}\left(\mathrm{OCH}_{3}\right)\right), 3.64\left(\mathrm{~s}, 3 \mathrm{H}, \mathrm{OCH}_{3}\left(\mathrm{COOCH}_{3}\right)\right), 3.67\right.$ (s, $\left.3 \mathrm{H}, \mathrm{OCH}_{3}\left(\mathrm{COOCH}_{3}\right)\right), 3.80\left(\mathrm{~d}, 3 \mathrm{H}, \mathrm{OCH}_{3}\left(\mathrm{P}\left(\mathrm{OCH}_{3}\right)\right), 4.00\right.$ $\left(\mathrm{dd}, 1 \mathrm{H},{ }^{3} \mathrm{~J}_{\mathrm{HH}}=9.00-12.00 \mathrm{~Hz},{ }^{2} J_{\mathrm{HP}} \approx 20 \mathrm{~Hz}, \mathrm{CH}\right), 4.40(\mathrm{dd}$, $\left.1 \mathrm{H},{ }^{3} J_{\mathrm{HH}}=9.00-12.00 \mathrm{~Hz},{ }^{3} J_{\mathrm{HP}} \approx 10.00 \mathrm{~Hz}, \mathrm{CH}\right) \mathrm{ppm}$.

2-(1-Acetyl-2-hydroxy-propenyl)-3-(dimethoxyphosphoryl)succinic acid dimethyl ester (11): Orange crystals, m.p. $97^{\circ} \mathrm{C}, 0.64 \mathrm{~g}$ (90\% yield); Anal. calcd.: C, 45.86; H, 6.18. Found: C, 44.32; H, $6.01 \%$. IR ( $\left.\mathrm{KBr}, \mathrm{v}_{\max }, \mathrm{cm}^{-1}\right): 3370-$ 3500 (broad peak, $\mathrm{OH}), 1720(\mathrm{C}=\mathrm{O}), 1650(\mathrm{C}=\mathrm{C}), 1259(\mathrm{P}=\mathrm{O})$, 850 (POCH3); ${ }^{1} \mathrm{H} \mathrm{NMR}\left(80 \mathrm{MHz}, \mathrm{CDCl}_{3}\right): 2.15$ (s, 3H, $\mathrm{CH}_{3}$ ), $2.25\left(\mathrm{~s}, 3 \mathrm{H}, \mathrm{CH}_{3}\right), 3.58\left(\mathrm{~s}, 3 \mathrm{H}, \mathrm{OCH}_{3}\left(\mathrm{P}\left(\mathrm{OCH}_{3}\right)\right), 3.59(\mathrm{~s}, 3 \mathrm{H}\right.$, $\left.\mathrm{OCH}_{3}\left(\mathrm{COOCH}_{3}\right)\right), 3.70\left(\mathrm{~s}, 3 \mathrm{H}, \mathrm{OCH}_{3}\left(\mathrm{COOCH}_{3}\right)\right), 3.80(\mathrm{~s}, 3 \mathrm{H}$, $\mathrm{OCH}_{3}\left(\mathrm{P}\left(\mathrm{OCH}_{3}\right)\right), 4.20\left(\mathrm{dd}, 1 \mathrm{H},{ }^{3} J_{\mathrm{HH}}=9.00-12.00 \mathrm{~Hz},{ }^{2} J_{\mathrm{HP}} \approx\right.$ $20.00 \mathrm{~Hz}, \mathrm{CH}), 4.80\left(\mathrm{dd}, 1 \mathrm{H},{ }^{3} J_{\mathrm{HH}}=9.00-12.00 \mathrm{~Hz},{ }^{3} J_{\mathrm{HP}} \approx\right.$ $10.00 \mathrm{~Hz}, \mathrm{CH}) \mathrm{ppm}$.

2-(1-Acetyl-2-ethoxy-2-hydroxy-vinyl)-3-(dimethoxyphosphoryl)succinic acid dimethyl ester (12) : Orange oil, $0.71 \mathrm{~g} \mathrm{(86 \%} \mathrm{yield);} \mathrm{Anal.} \mathrm{calcd.:} \mathrm{C,} \mathrm{45.27;} \mathrm{H,} \mathrm{6.38.} \mathrm{Found:} \mathrm{C,}$ 44.97; H, $6.60 \%$. IR (KBr, $\left.v_{\max }, \mathrm{cm}^{-1}\right)$ : 3300-3620 (broad peak, OH), $1729(\mathrm{C}=\mathrm{O}), 1620(\mathrm{C}=\mathrm{C}), 1248(\mathrm{P}=\mathrm{O}), 781$ $\left(\mathrm{POCH}_{3}\right) ;{ }^{1} \mathrm{H}$ NMR $\left(80 \mathrm{MHz}, \mathrm{CDCl}_{3}\right): 1.30\left(\mathrm{t}, 6 \mathrm{H}, 2 \mathrm{CH}_{3}\right), 3.35$ $\left(\mathrm{s}, 6 \mathrm{H}, 2 \mathrm{OCH}_{3}\left(\mathrm{P}\left(\mathrm{OCH}_{3}\right)\right), 3.71\left(\mathrm{~s}, 3 \mathrm{H}, \mathrm{OCH}_{3}\left(\mathrm{COOCH}_{3}\right)\right), 3.77\right.$ $\left(\mathrm{s}, 3 \mathrm{H}, \mathrm{OCH}_{3}\left(\mathrm{COOCH}_{3}\right)\right), 4.15\left(\mathrm{q}, 4 \mathrm{H}, 2 \mathrm{CH}_{2}\right), 4.40(\mathrm{dd}, 1 \mathrm{H}$, $\left.{ }^{3} J_{\mathrm{HH}}=9.00-12.00 \mathrm{~Hz},{ }^{2} J_{\mathrm{HP}} \approx 20 \mathrm{~Hz}, \mathrm{CH}\right), 5.00\left(\mathrm{dd}, 1 \mathrm{H},{ }^{3} J_{\mathrm{HH}}=\right.$ $\left.9.00-12.00 \mathrm{~Hz},{ }^{3} J_{\mathrm{HP}} \approx 10.00 \mathrm{~Hz}, \mathrm{CH}\right) \mathrm{ppm}$.

\section{RESULTS AND DISCUSSION}

The reaction of trimethyl phosphite (1) and dimethyl acetylenedicarboxylate (2) in the presence of dimedone (3) as the proton source/nucleophile leads to 2-(dimethoxy-phosphoryl)-3-(2-hydroxy-4,4-dimethyl-6-oxo-cyclohex-1-enyl)succinic acid dimethyl ester (4) in $91 \%$ yields (Scheme-I). The reaction was completed by mixing diethyl ether with dimedone (3), then respectively trimethyl phosphite and dimethyl acetylenedicarboxylate (DMAD) were added slowly. The reaction was complete within $48 \mathrm{~h}$. The structure of compound as 1:1:1 adducts was deduced from its elemental analyses, IR and ${ }^{1} \mathrm{H}$ NMR. The ${ }^{1} \mathrm{H}$ NMR spectrum of (4) in $\mathrm{CDCl}_{3}$ exhibited two doublets recognized as arising for the two methoxy $(\delta=3.59$ and $3.80 \mathrm{ppm})$ groups. The two singlets at $(\delta=3.64$ and $3.67 \mathrm{ppm})$ belong to the ester methoxy protons. Observation of a doublet of doublet at $\left(\delta=4.00 \mathrm{ppm},{ }^{3} J_{\mathrm{HH}}=\right.$ $\left.9.00-12.00 \mathrm{~Hz},{ }^{2} J_{\mathrm{HP}}=20.00 \mathrm{~Hz}\right)$ and $\left(\delta=4.40 \mathrm{ppm},{ }^{3} J_{\mathrm{HH}}=\right.$ $9.00-12.00 \mathrm{~Hz},{ }^{3} J_{\mathrm{HP}}=10.00 \mathrm{~Hz}$ ) for the vicinal methine protons in (4), indicates the dominance of the anti arrangement. Since compound (4) posses two stereogenic centers, two diastereomers with anti HCCH arrangement are possible (SchemeII). Although we have not yet established the mechanism of the reaction between trimethyl phosphite and DMAD in the presence of dimedone in an experimental manner, a possible explanation is proposed in Scheme-III. On the basis of the<smiles>CC1(C)CC(=O)CC(=O)C1</smiles>

3
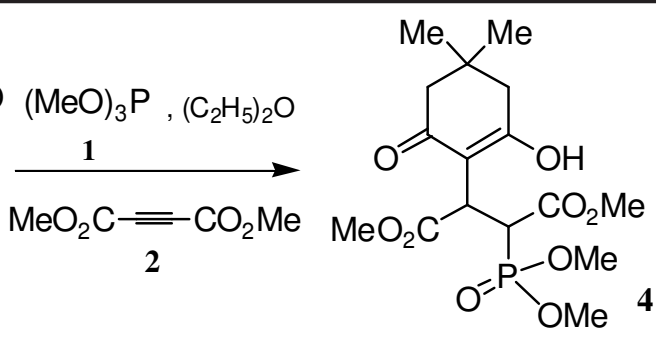

Scheme-I: Synthesis of 2-(dimethoxy-phosphoryl)-3-(2-hydroxy-4,4dimethyl-6-oxo-cyclohex-1-enyl)succinic acid dimethyl ester (4)<smiles>COC(=O)[C@H](C(C)=O)[C@@H](C(C)=O)[C@H](O)P(=O)(OC)OC</smiles>

$(2 S, 3 R)$ or $\left(2 R^{\star}, 3 S^{\star}\right)$

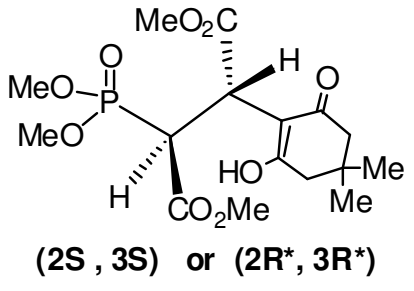

$(2 S, 3 S)$ or $\left(2 R^{\star}, 3 R^{\star}\right.$
Scheme-II: Diastereomers of 2-(dimethoxy-phosphoryl)-3-(2-hydroxy-4, 4dimethyl-6-oxo-cyclohex-1-enyl)succinic acid dimethyl ester (4)

well established chemistry of phosphorus nucleophiles ${ }^{4,5}$, it is reasonable to assume that compounds (4) result from initial addition of trimethyl phosphite to the activated dimethyl acetylenedicarboxylate and subsequent protonation of the reactive 1:1 adduct by dimedone. Following on, the positively charged ion (6) is attacked by the anion of the 1,3-dicarbonyl ion(7) to produce compound (8) that is converted to compound (9). Then by attack of the oxygen atom of the anion to phosphorus cation, to generate compound (10), which is hydrolyzed to give compound (4). Since the reaction was carried out under an ordinary atmosphere, the conversion of compound (10) to (4) is presumably accomplished by the moisture from the air (Scheme-III). The reaction of trimethyl phosphite with DMAD in the presence of acetyl acetone and diethyl malonate gave (11) and (12) in high yields (SchemeIV). Observation of ${ }^{3} J_{\mathrm{HH}}=9.00-12.00 \mathrm{~Hz}$ and, ${ }^{3} J_{\mathrm{HH}}=9.00-$ $12.00 \mathrm{~Hz}$ for the vicinal methine protons (11) and (12) compounds, show the dominance of the anti arrangement and (2S, 3R) or (2R, 3S) diastereoisomer respectively.

Finally, the reaction of trimethyl phosphite, dimethyl acetylenedicarboxylate (DMAD) and 1,3-dicarbonyl compounds such as dimedone, acetyl acetone and diethyl malonate provides a simple one-pot synthesis of stable dimethoxyphosphoryl succinic acid dimethyl esters of potential synthetic and pharmaceutical interest. The present method carries the advantage that not only is the reaction performed under neutral conditions, but also the substances can be used without any activation or modification.

\section{Conclusion}

Dimethoxyphosphoryl succinic acid dimethoxy ester derivatives (4), (11) and (12) have been synthesized from the reaction of trimethyl phosphite, dimethyl acetylenedicarboxylate and 1,3-dicarbonyl compounds. 

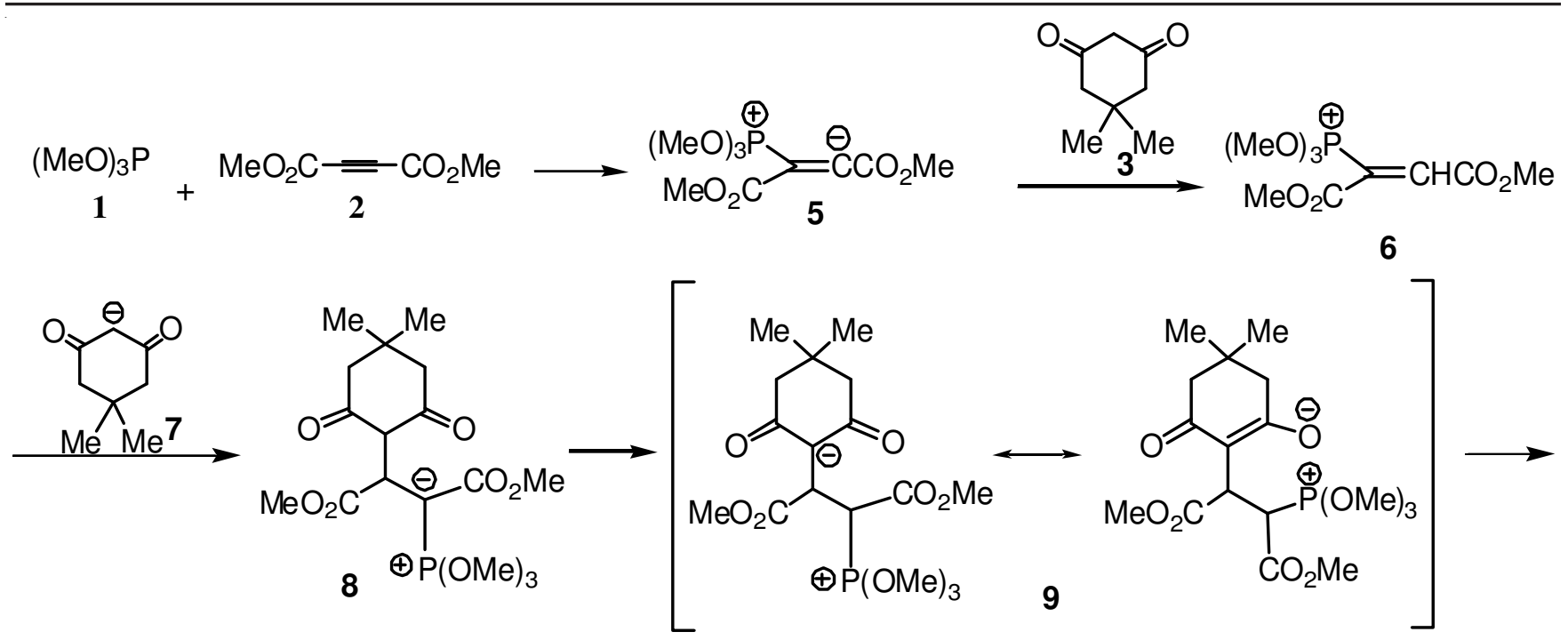<smiles>COP1OC2=C(C(=O)CC(C)(C)C2)C(C(C)=O)P1OC</smiles><smiles>COC(=O)C(C(C)O)C(OC)C(C(C)O)P(=O)(OC)OC</smiles>

Scheme-III: A possible mechanism for synthesis of 2-(dimethoxy-phosphoryl)-3-(2-hydroxy-4,4-dimethyl-6-oxo-cyclohex-1-enyl)succinic acid dimethyl ester (4)<smiles>COC(=O)C(C(C(C)=O)=C(C)O)C(OC)P(=O)(OC)OC</smiles>

11<smiles>CCOC(=O)C(=C(O)OCC)C(C(C)OC)C(C)OP(=O)(OC)OC</smiles>

12

Scheme-IV: Structures of 2-(1-acetyl-2-hydroxy-propenyl)-3-(dimethoxyphosphoryl)succinic acid dimethyl ester (11)and 2-(1-acetyl-2ethoxy-2-hydroxy-vinyl)-3-(dimethoxy-phosphoryl)succinic acid dimethyl ester (12)

\section{ACKNOWLEDGEMENTS}

The authors are so grateful for kind cooperation of Prof. Issa Yavari (Department of Chemistry, Tarbiat Modarres University, Tehran, Iran) and to the Vice-Chancellor for Research of Kerman University of Medical Sciences for financial support.

\section{REFERENCES}

1. F. Palacios, C. Alonso and J.M. de los Santos, Chem. Rev., 105, 899 (2005) and the references cited therein.

2. R. Engel and J.I. Cohen, Synthesis of Carbon-Phosphorus Bonds, Ch. 1, CRC Press, New York, vol. 1 (2004).

3. R.R. Holmes, Acc. Chem. Res., 37, 746 (2004).

4. B.E. Maryanoff and A.B. Reitz, Chem. Rev., 89, 863 (1989).

5. (a) I. Yavari and M.H. Mosslemin, Tetrahedron, 54, 9169 (1998); (b) I. Yavari, M.H. Mosslemin and A.R. Montahaei, J. Chem. Res., (S) 576 (1998); (c) I. Yavari, M. Adib and L. Hojabri, Tetrahedron, 57, 7537 (2001); (d) I. Yavari and M. Adib, Tetrahedron, 57, 5873 (2001); (e) I. Yavari and A. Alizadeh, Tetrahedron, 57, 9873 (2001); (f) I. Yavari, M. Adib and M.H. Sayahi, Tetrahedron Lett., 43, 2927 (2002); (g) I. Yavari, M. Adib and M.H. Sayahi, J. Chem. Soc., Perkin Trans. I, 1517 (2002); (h) I. Yavari, M. Anari-Abbasinejad and Z. Hossaini, Org. Biomol. Chem., 1, 560 (2003); (i) I. Yavari and N. Zabarjad-Shiraz, Monatsh Chem., 134, 445 (2003); (j) I. Yavari, M. Adib, Sh. Abdolmohammadi and M. Aghazadeh, Monatsh. Chem., 134, 1093 (2003); (k) I. Yavari and M. Bayat, Monatsh. Chem., 134, 1221 (2003); (1) I. Yavari and A. Alizadeh, Synthesis, 237 (2004); (m) M.H. Mosslemin, I. Yavari, M. Anary-Abbasinejad and M.R. Nateghi, Synthesis, 1029 (2004); (n) I. Yavari and A. Alizadeh, Mendeleev Commun., 15, 154 (2005).

6. A.J. Arduago and C.A. Stewart, Chem. Rev., 94, 1215 (1994).

7. K.M. Pietrusiewiz and M. Zabloka, Chem. Rev., 94, 1375 (1994).

8. H.J. Bestmann and O. Vostrowsky, Top. Curr. Chem., 109, 85 (1983).

9. M. George, V.S.K. Khetan and P.K. Gupta, Adv. Heterocycl. Chem., 19, 354 (1976).

10. R. Burgada, Y. Leroux, M. Zabloka and Y.U. Elkhoshnieh, Tetrahedron Lett., 22, 3533 (1981).

11. H.R. Hudson, The Chemistry of Organophosphorus Compounds, Wiley, New York, vol. 1, p. 386 (1990).

12. I. Yavari, Z. Hossaini and E. Karimi, Monatsh. Chem., 138, 1267 (2007).

13. I. Yavari, Z. Hossaini and A. Alizadeh, Monatsh. Chem., 137, 1083 (2006). 